\title{
Conflicts of Criminal Jurisdiction in the European Union
}

\author{
FRANK ZIMMERMANN*
}

\section{Introduction}

The European Union shall be (or become) an 'area of freedom, security and justice' - this is what Article 67(1) of the Treaty on the Functioning of the European Union (TFEU) solemnly proclaims. It is the aim of this contribution to show that if this is to be taken seriously, conflicts of criminal jurisdiction between the Member States of the Union should no longer be ignored. Rather, the prevention of such conflicts is of paramount importance for the development of a coherent criminal justice system in the European Union (infra 2). Therefore, an attempt will be made to offer guidelines for a European solution to this problem in the second part of this contribution (infra 3).

As an initial step, however, the topic of this contribution must be defined in somewhat more detail: First, this study will focus on conflicts of jurisdiction between Member States of the Union ('horizontal' conflicts). Overlaps of supranational and national prosecution competences ('vertical' conflicts) will not be addressed-although some of the proposals made here can certainly be transferred to vertical conflicts, depending on the precise

Postdoctoral Research Fellow at the Chair of German, European and International Criminal Law, Criminal Procedure and Business Criminal Law (Prof. Dr. Helmut Satzger), LudwigMaximilians-Universität München.

This is an Open-access article distributed under the terms of the Creative Commons Attribution 3.0 Unported License (http://creativecommons.org/licenses/ by/3.0/), permitting all use, distribution, and reproduction in any medium, provided the original work is properly cited. 
delimitation of each level's competences. ${ }^{1}$ Second, only multiple prosecution interests regarding natural persons shall be analysed. Possible solutions to more complex situations where multi-national legal entities are involved must therefore be discussed elsewhere. ${ }^{2}$ Finally, this article will be restricted to so-called 'positive' conflicts of jurisdiction, i.e. cases where different Member States actually want to or at least could exercise their criminal jurisdiction. 'Negative' conflicts of jurisdiction, by contrast, can arise when no state is willing or able to prosecute. They will therefore often lead to impunity. Certainly, such negative conflicts are of relevance in EU law, particularly because there is a need to effectively combat fraud against the Union's financial interests (see Article 325 TFEU). Nevertheless, they shall not be analysed in further detail here as the competence of the Union to legislate in this field (and thus oblige Member States to prosecute) has already been thoroughly discussed. ${ }^{3}$

\section{Why Are Conflicts of Criminal Jurisdiction Problematic?}

Before it is possible to offer a convincing solution to conflicts of criminal jurisdiction, it is first necessary to ascertain the need to do so: such conflicts are not really a new phenomenon. Rather, it can be assumed that there always have been cases regarding which several states were able to apply their criminal laws, and traditionally this has not raised great concern. ${ }^{4}$ The following part is therefore dedicated to the question of what in the situation of the Union is so specific that a different view ought to be taken. As a first step, the interests which are affected by conflicts of criminal jurisdiction will be analysed. It is submitted that such conflicts jeopardise essential interests of both the individual who faces prosecution and the Member States involved.

1 Zimmermann, Choice of Forum and Choice of Law under the Future Regulation on the Establishment of a European Public Prosecutor's Office, in The European Public Prosecutor's Office. Legal and Criminal Policy Perspectives, ed. Asp (Skrifter utgivna av Juridiska fakulteten vid Stockholms universitet 2015), pp.156-177; Wasmeier, The Choice of Forum by the European Public Prosecutor in The European Public Prosecutor's Office. An Extended Arm or a Two-Headed Dragon?, ed. Erkelens, Meij \& Pawlik (Springer 2014), pp. 139-160. For a more in depth analysis see Neumann, Vertikale Kompetenzverteilung im Strafrechtssystem der EU (Nomos 2015); Reinbacher, Strafrecht im Mehrebenensystem (Nomos 2015).

2 Schneider, Corporate Criminal Liability and Conflicts of Jurisdiction in Regulating Corporate Criminal Liability, ed. Brodowski et al. (Springer 2014), pp. 249-260.

3 Satzger, International and European Criminal Law (C.H. Beck 2012), \$ 6 margin nos. 20-30; Asp, Criminal Law Competence of the EU (Skrifter utgivna av Juridiska fakulteten vid Stockholms universitet 2012), pp. 142-157; Zimmermann, The Implications of the Treaty of Lisbon on Criminal Law, in The EU and National Constitutional Law, ed. Huber (Boorberg 2012), pp. 7374.

4 There were, however, several early initiatives aiming at the prevention of conflicts of jurisdiction, see for instance a draft Council of Europe Convention, Recommendation 420 (1965), Assembly debate on $29^{\text {th }}$ January 1965 (24 $4^{\text {th }}$ Sitting); see also Ambos, Vor $\$ \$ 3-7$ in Münchner Kommentar zum Strafgesetzbuch, $2^{\text {nd }}$ edition, ed. Joecks and Miebach (C.H. Beck 2011), margin nos. 56 ff. 


\subsection{Interests affected by 'concrete' conflicts of criminal jurisdiction}

To illustrate this contention, the following case may serve as an example of a 'concrete' conflict of jurisdiction, i.e. a situation where several Member States actually can (and want to) prosecute one and the same act. ${ }^{5}$

Case 1:

At a conference in Munich (Germany), a Finnish national A mixes poison into the beer of her Danish colleague T in order to kill him. However, the poison does not show its effects immediately. Therefore, T boards a flight back to Denmark. During a stopover at Arlanda airport (Sweden), T suddenly feels sick, collapses and dies from the poison.

In such a homicide case, it can reasonably be assumed that the act constitutes a criminal offence in all jurisdictions involved, i.e. in Germany, Sweden, Finland and Denmark. According to well-established principles of criminal jurisdiction, ${ }^{6}$ each of these four Member States could ${ }^{7}$ prosecute A: Germany and Sweden based on the principle of territoriality because the relevant act was committed on German soil ${ }^{8}$ and caused effects in Sweden. ${ }^{9}$ Finland could claim jurisdiction over the case because A is a Finnish national (principle of active personality), ${ }^{10}$ and the same is true for Denmark because $\mathrm{T}$ is a Danish national (protective principle or principle of passive personality). ${ }^{11}$ Of course there are several more principles which allow states to extend their criminal jurisdiction beyond their own borders (most importantly the principle of state protection). If one moreover takes into account the fact that various shades of these principles exist, ${ }^{12}$ it appears reasonable to state that overlaps of different (Member) States' criminal jurisdiction are not at all an exotic exception. Taken together with the increased mobility of citizens (greatly promoted by Union law) as well as technical progress which makes it possible to communicate,

5 The notion is taken from Vander Beken et al., Finding the best place for prosecution: European study on jurisdiction criteria (Maklu 2002), p. 18.

$6 \quad$ For an overview see Satzger 2012, $\$ 4$.

7 Of course that does not mean that all states make use of this possibility. For instance, the principle of passive personality is not at all recognised in all jurisdictions, also because it is strongly debated to which extent it is in conformity with international law. See for instance Elholm \& Feldtmann, Nordic trends of jurisdiction, in Criminal Jurisdiction. A Nordic Perspective, eds. Elholm \& Feldtmann (Djøf 2014), pp. 152 ff.

$8 \quad$ Section 9(1) of the German Penal Code.

$9 \quad$ For details see Cornils, Sweden, in Elholm \& Feldtmann 2014, p. 134.

10 For details see Suominen, Finland in Elholm \& Feldtmann 2014, pp. 49 ff.

11 For details see Cornils \& Vagn Greve, Denmark in Elholm \& Feldtmann 2014, pp. 26 ff.

12 For the territoriality principle see the comparative analysis by Sinn, Das Strafanwendungsrecht als Schlüssel zur Lösung von Jurisdiktionskonflikten? Rechtsvergleichende Beobachtungen in Conflicts of jurisdiction in cross-border crime situations, ed. Sinn (Universitätsverlag Osnabrück 2012), pp. 515-518. 
trade across borders and so forth, this situation creates a considerable potential for conflicts of criminal jurisdiction between Member States of the Union.

Thus, two questions arise. The first one is: should each of the Member States involved be allowed to initiate investigations and prosecute the perpetrator? A negative answer leads to the second question: in which Member State should proceedings take place?

\subsubsection{Interests of the individual concerned}

From the individual's perspective, conflicts of criminal jurisdiction entail a risk of multiple prosecution and punishment in different Member States: in our first case A would in principle-special rules applicable within the EU will be dealt with infra 2.4have to face criminal proceedings in all four jurisdictions. This implies that investigative measures may be ordered simultaneously, which would make it very complicated and expensive to organise an effective defence. ${ }^{13}$ Furthermore, some measures may have to be repeated in each Member State. Compared to criminal proceedings in just one state, the intensity of the interference with the suspect's fundamental rights would thus be increased. ${ }^{14}$ Finally, if A were to be convicted in all four Member States, the accumulated sanctions could go far beyond what is proportionate: hypothetically she could be punished four times, as if she had killed four persons instead of one. Even if the Member States concerned reduced their respective sanctions to the extent that a prior sentence has already been enforced abroad for the same crime, ${ }^{15}$ the most severe punishment regime would ultimately apply. Such an automatic predominance of the most punitive criminal justice system is hardly convincing in an 'area of freedom, security and justice.16

Even when there is no risk of repeated proceedings - for instance because the Member States involved decide not to exercise their ius puniendi if the act has already been punished abroad - the situation for the suspect remains problematic. Then the crucial ques-

13 Nestler, European defence in trans-national criminal proceedings in A Programme for European Criminal Justice, ed. Schünemann (Carl Heymanns 2006), p. 418; Szwarc, Eurodefence - Support for the Defence in A Programme for European Criminal Justice, ed. Schünemann (Carl Heymanns 2006), pp. 429 ff.; Zimmermann 2014, p. 178; in the context of mutual recognition Satzger 2012, $\$ 8$ margin no. 22 .

14 Lagodny, Empfiehlt es sich eine europäische Gerichtskompetenz für Strafgewaltskonflikte vorzusehen? (2001, full text available at http://www.uni-salzburg.at/strafrecht/lagodny), pp. 36 ff.; Eser \& Burchard, Interlokales 'ne bis in idem' in Europa? Von 'westphälischem' Souveränitätspathos zu europäischem Gemeinschaftsdenken in Freiheit, Sicherheit und Recht: Festschrift für Jürgen Meyer zum 70. Geburtstag (Nomos 2006), p. 504; Zimmermann 2014, pp. $177 \mathrm{ff}$.

15 See, for instance, section 51(3) German Penal Code.

16 See in the context of mutual recognition Schünemann, Europäischer Haftbefehl und EUVerfassungsentwurf auf schiefer Ebene - Die Schranken des Grundgesetzes, in ZRP (2003), p. 187. 
tion is where the first trial will take place, or in other words which Member State is to be the forum state. This is of great importance as the law that is applied at trial depends on the forum state. This is one of the major differences when compared to the situation in a purely domestic case, where different courts may be competent, yet the same law always applies. ${ }^{17}$ On the one hand, the applicable law defines the procedural rules, such as those on the legal preconditions of investigative measures, the admissibility of certain pieces of evidence, the position of the accused in trial and their right to appeal. Thus, where the trial takes place can be crucial for the likelihood of a conviction. On the other, it also determines the provisions of substantive law that are applicable. ${ }^{18}$ As long as the act is criminalised in all Member States, this matter may at first sight appear negligible. However, the applicable law still determines the sanction in the particular case. Considering the fact that the level of sanctions for one and the same offence can differ greatly within the EU, it will often be impossible for the accused to foresee the severity of the sanction that could be imposed. In this regard, our first case is certainly not the most impressive example because A must expect a long prison sentence in all the jurisdictions involved. But for many other offences the picture is quite different, particularly because Member States' criminal law provisions often differ with regard to aggravating and mitigating circumstances. ${ }^{19}$ Moreover, there may be a possibility to dispense with prosecution in some Member States, but not in all. This can lead to a situation where an act can entail a severe prison sentence in one Member State whereas it goes (almost) unpunished in another. As a result, the citizen will often have no idea of the penalty that is to be expected in the actual case and thus of how strongly national law disapproves his conduct. Such a lack of foreseeability can amount to a violation of the principle of legality (nullum crimen sine lege certa), which guarantees the foreseeability not only of criminal punishment as such, but also of the possible level of the sanction. ${ }^{20}$

This leads to the conclusion that where the case is to be tried is decisive for the outcome of the proceeding. In an 'area of justice' this should therefore not be determined by coincidence, but on the basis of objective and 'just' criteria. Furthermore, there is an obvious danger that prosecution authorities might be tempted to allocate the case to a Member State where the legal situation is most favourable for a conviction. In other words, there is

17 SEC (2005) 1767, p. 31; Eisele, Jurisdiktionskonflikte in der Europäischen Union: Vom nationalen Strafanwendungsrecht zum Europäischen Kollisionsrecht, in 125 Zeitschrift für die gesamte Strafrechtswissenschaft (2013), p. 27.

$18 \quad$ Lagodny 2001, p. 114.

19 For instance, a theft committed in a train can entail a prison sentence of up to six months in Austria (section 127 Austrian Penal Code), up to five years in Germany (section 242(1) German Penal Code), or between three and ten years in Italy (Article 625(1) Italian Penal Code); see also Zimmermann 2014, p. 175 ff.

20 Camilleri v. Malta, ECtHR Judgement of 22.01.2013, appl. no. 42931/10, paras. 40 ff.; Roxin, Strafrecht Allgemeiner Teil Band I, (4 $4^{\text {th }}$ ed., C.H. Beck 2006), $\$ 5$ margin nos. $80 \mathrm{ff}$. 
a risk of forum shopping to the detriment ${ }^{21}$ of the accused. An already undesirable situation where the location for the trial is determined by coincidence, would be even worse if prosecution authorities had the option of freely choosing a jurisdiction. ${ }^{22}$ This should, of course, not be misunderstood as an expression of general mistrust towards prosecutors. But under the rule of law, even a small risk of manipulation in criminal proceedings must be avoided. ${ }^{23}$ Such important decisions as which jurisdiction a suspect will be tried in, should therefore be made by the legislator-at least to the greatest possible extent.

Thus, the interests of the individual can be summarised as follows: (1) repeated and parallel proceedings for the same act have to be avoided, (2) the case should not be allocated in a way that one-sidedly disadvantages the suspect and (3) it must be ensured that the risk of punishment as such and the applicable sanctions are foreseeable.

\subsubsection{Interests of the Member States involved}

The interests of the Member States involved, by contrast, can mainly ${ }^{24}$ be derived from the purpose behind criminal punishment. Each of the Member States in our case will aim at the prevention of, deterrence from and retaliation for an act that is a serious criminal offence in its jurisdiction. However, it could be argued that within an 'area of freedom, security and justice' it should not make a difference in which Member State the trial takes place and where the sanction is imposed. ${ }^{25}$ Indeed, this reasoning would reflect very well

21 Some have argued that there is also a risk of forum shopping by the suspect, who could surrender to the police in the Member State where the legal situation is most favourable for him, see Eser, Kritische Würdigung der Modellentwürfe eines Regelungsmechanismus zur Vermeidung von Jurisdiktionskonflikten in Conflicts of jurisdiction in cross-border crime situations, ed. Sinn (Universitätsverlag Osnabrück 2012), pp. 566 ff. However, the states concerned can easily solve this problem, for instance by limiting their jurisdiction or allowing for an extradition. The suspect, by contrast, does not have such possibilities. However, a regulation that defines which Member State is competent to try the case (see infra 3.4) would also solve this problem.

22 Lagodny 2001, p. 67; Panzavolta, Choice of Forum and the Lawful Judge Concept in Choice of Forum in Cooperation against EU Financial Crime, ed. Luchtman (Eleven International 2013), p. 162; Luchtman, Choice of Forum and the Prosecution of Cross-Border Crime in the European Union - What Role for the Legality Principle? in Choice of Forum in Cooperation against EU Financial Crime, ed. Luchtman (Eleven International 2013), p. 11.

23 Compare Ligeti/Weyembergh, The European Public Prosecutor's Office: Certain Constitutional Issues in The European Public Prosecutor's Office, ed. Erkelens, Meij \& Pawlik (Springer 2014), p. 68 .

$24 \quad$ All Member States willing to prosecute will also be interested in speedy and uncomplicated cooperation with other Member States whose assistance is needed.

25 In this sense see Thomas, Das Recht auf Einmaligkeit der Strafverfolgung. Vom nationalen zum internationalen ne bis in idem (Nomos 2002), pp. 128 ff. and 322 ff.; Klip, European Criminal Law, $2^{\text {nd }}$ edition (Intersentia 2012), p. 475. Of a different opinion Eckstein, Grund und Grenzen transnationalen Schutzes vor mehrfacher Strafverfolgung in Europa, in 124 Zeitschrift für die gesamte Strafrechtswissenschaft (2012), pp. $498 \mathrm{ff}$. 
the principle of mutual recognition of judicial decisions in criminal matters, cf. Article 82(1) TFEU. But can a Member State really be sure that its interest in prosecution will duly be taken into account when the case is adjudicated in another Member State?

It is submitted ${ }^{26}$ that two aspects can call this into doubt: firstly, the act may be criminalised in the other Member State, but on the basis of entirely different considerations. If, for instance, Member State X wants to prosecute A for an offence of espionage, it could hardly be expected to refrain from prosecution when the act is merely classified as unlawful entry in Member State B. In such cases a common basis for the assessment of the wrongfulness of the act is missing. As a consequence, a conviction in Member State B would send out a completely different message than one in Member State A. However, not every minor deviation between the criminal laws of different Member States can justify each of them having a legitimate interest to conduct its own proceeding. In particular, the level of sanctions cannot be but one aspect indicating the lack of a common value basis. Rather, a conviction abroad should be regarded as sufficient as long as the 'core of the reproach' made to the offender is identical. ${ }^{27}$ This is the case e.g. where differences in a theft case exist only with regard to aggravating circumstances, as long as the central element of the offence is the violation of another person's property. In the espionage example, by contrast, such a common basis would be missing. The second aspect that could motivate a Member State to initiate its own proceedings and not entrust prosecution to another Member State is the concern that the latter might not conduct the proceedings in an adequate way. That assumption could be based, for instance, on a lack of personnel or technical resources, or on a manifest unwillingness to prosecute. ${ }^{28}$

This being said, it is only a small step to concede that a Member State can have a legitimate interest in prosecution even after a final decision has been handed down in another Member State. However, at that stage it needs to be taken into account that a final decision normally creates a certain confidence on the part of the defendant that no further proceedings will be initiated. Thus, a possible interest in prosecuting the act a second time has to be weighed against the defendant's interest in legal certainty (see infra. 3.4.4).

\subsection{Interests affected by 'abstract' conflicts of criminal jurisdiction}

The following remarks regard so-called 'abstract' conflicts of criminal jurisdiction, i.e. situations where an act is linked to several Member States, of which only one can pros-

26 In detail, see Zimmermann 2014, pp. 195-200.

27 Compare also Böse, Der Grundsatz 'ne bis in idem' in der Europäischen Union, in Goltdammer's Archiv für Strafrecht (2003), pp. 760 ff.; Thomas 2002, pp. 168 and 225; sceptical Eser \& Burchard 2006, p. 511.

28 Vogel, Internationales und europäisches ne bis in idem, in Festschrift für Friedrich-Christian Schroeder zum 70. Geburtstag, ed. Hoyer et al. (Müller 2006), p. 882. 
ecute (for instance because the others have not implemented a particular jurisdictional principle or because they have not criminalised the respective act). A second case may demonstrate that even more elementary questions can arise in that scenario.

Case 2:

This time, $A$ and T are both German nationals. At a conference in Munich, A provides $T$ with a lethal dose of barbiturates because $T$ wants to take his own life and has asked $A$ to help him. T immediately takes almost all the pills along with a glass of beer. However, the dose is too small and does not affect $T$ immediately. $T$ is disappointed and enters a train to Austria, where he wants to recreate and rethink his decision. Soon after his arrival in Vienna, the drugs suddenly take effect and T dies.

Here, the starting point is quite similar: the case is linked to Germany and Austria. But it differs from the original case in one very important aspect: this type of 'assisted suicide' is not punishable in Germany, ${ }^{29}$ whereas the Austrian penal code does contain a provision criminalising such behaviour. ${ }^{30}$ Of course it might be objected that this is not a conflict of jurisdiction in a strict sense because only Austria can be interested in prosecuting A. However, it is submitted that also here such a conflict exists, as two legal regimes can claim to be applicable. Thus, it is not the jurisdiction to adjudicate which is of interest, but the jurisdiction to prescribe. Nevertheless, this situation should likewise be discussed under the headline of conflicts of jurisdiction because the problems that arise are quite similar: once again, the interest of the Member State that is in the position to prosecute (i.e. Austria) is to deter from, prevent, and retaliate for a behaviour that is a criminal offence in its domestic legal order. The interests of the perpetrator A can be deemed even more fundamental than in our original case: from her perspective, the problem is that she committed an act in a place where that act was not illegal, and at that moment nothing was indicating that Austria might have jurisdiction. Unlike in the first case, she could therefore hardly foresee that she would be criminally liable at all.

Finally, it becomes obvious that a conflict exists in this case when we take into consideration that also interests of the German state are involved. Germany could claim that an act which is committed on German soil should not be subjected to Austrian law. This is because the German legislator might have had good reasons not to criminalise the actual conduct, for instance when this decision has been based on constitutional considerations. As a consequence, Germany can claim that this decision against criminalisation be respected by other Member States. ${ }^{31}$ Furthermore, a positive obligation to ensure fundamental rights of German citizens might be derived from German (constitutional) law.

29 Roxin, Strafrecht Allgemeiner Teil Band II (C.H. Beck 2003), \$26 margin no. 3.

30 Section 77 of the Austrian Penal Code also covers assistance provided to someone killing himself.

31 It can even be argued that this can be derived from international law, see Ambos 2011, margin no. 11 . 
In other words, Germany might have an interest to protect its citizen A from criminal prosecution that she could not foresee.

\subsection{Legal foundation of these interests}

So far, it can be concluded that conflicts of jurisdiction appear in two forms: as concrete conflicts (overlapping jurisdiction to adjudicate) and abstract conflicts (overlapping jurisdiction to prescribe). As seen above, both types are problematic for the persons and states involved. This alone would already justify the demand that a mechanism to prevent and solve such conflicts be established. However, this claim would be even more compelling if the interests described above were also legally guaranteed. The legislative bodies in the EU might then even be positively obliged to take measures in order to protect these interests.

In national (often constitutional) law, the individual's interest in being able to foresee criminal liability as well as the sanction that can be imposed is protected by the already mentioned principle of legality, nullum crimen, nulla poena sine lege. Similarly, it can be argued that a lack of clarity regarding the applicable rules of procedure as well as the possibility of forum shopping by prosecutors to the suspect's detriment would-in an inner-state context-collide with the right to be sentenced in a fair trial and by a tribunal established by law, cf. Article 6(1) ECHR. ${ }^{32}$ These two guarantees therefore put an obligation on national legislators to establish clear rules in the fields of substantive criminal law and criminal procedure. ${ }^{33}$ Finally, the problems arising from parallel proceedings make an effective defence more complicated (if not impossible) and thus conflict with essential rights of the defendant. However, in the two cases that we have just discussed, there was no shortcoming in the applicable national laws-the national legislators had not made any mistake. ${ }^{34}$ The problems regarding the foreseeability of criminal liability and of the applicable procedural law rather stem from the transnational dimension of the two cases. The same is true for the right to an effective defence. This allows for the conclusion that legitimate interests of suspects-although well-recognised in a purely domestic criminal

32 Compare Coëme et al. v. Belgium, ECtHR judgement of 22.06.2000, appl. no. 32492/96, paras. 98 ff., particularly para. 101; Lavents v. Latvia, ECtHR Judgement of 22.11.2002, appl. no. 58442/00, para. 114; Savino et al. v. Italy, ECtHR judgement of 28.04.2009, appl. no. 17214/05, para. 94; Panzavolta 2013, pp. 149 ff.; Zimmermann 2014, pp. 236-238.

33 Zimmermann, Third Demand: Respect for the Principle of Legality and Judicial Principles in European Criminal Proceedings in A Manifesto on European Criminal Procedure Law, ed. European Criminal Policy Initiative (Skrifter utgivna av Juridiska fakulteten vid Stockholms universitet 2014), pp. 232 ff.; Zimmermann 2015, pp. 161-165.

34 Jeßberger, Der transnationale Geltungsbereich des deutschen Strafrechts (Mohr Siebeck 2011), p. 143; Pohl, Vorbehalt und Anerkennung: Der europäische Haftbefehl zwischen Grundgesetz und europäischem Primärrecht (Nomos 2009), p. 160; Lagodny 2001, p. 115; Zimmermann 2014, pp. 149-153. 
proceeding - are not effectively protected in cross-border cases. ${ }^{35}$ Since national legislators traditionally tend to focus on their internal affairs, precise rules on the rights of individuals in transnational situations are rare. To use a common metaphore, one could say that the suspect is left 'sitting between two chairs' because the case is linked to (at least) two jurisdictions, but none of them fully ensures judicial guarantees in that particular scenario. This phenomenon can be described as 'cross-border gap'.

However, the fact that the interests of individuals who are affected by conflicts of criminal jurisdiction are recognised in national law-and even in national constitutional lawallows for the conclusion that they ought to be protected. And which other institution could be the addressee of this demand than the legislator of the European Union? If the Union is to become 'an ever closer union among the peoples of Europe' as Article 1 of the Treaty on European Union (TEU) proclaims, and a single area of justice, as it is stipulated in Article 67 TFEU, that means no less than that the Union is gradually developing structures which equal those of a state. But then it should also provide legal structures in the field of criminal justice that can keep up with those of a state. ${ }^{36}$ Therefore it should be considered the task of the Union to close the 'cross-border gap' in the protection of essential criminal law and procedure guarantees, such as nullum crimen sine lege and the right to be judged by a court established by law in a fair trial. This view is supported by Article 82(1)(b) TFEU, which states that 'the European Parliament and the European Council [...] shall adopt measures to [...] prevent and settle conflicts of jurisdiction between the Member States' (emphasis added). ${ }^{37}$ As far as the interests of the person who shall be prosecuted are concerned, ${ }^{38}$ Article 51(1)(2) of the Charter on Fundamental Rights of the EU (CFR) provides an additional legal basis for an obligation on the part of the Union to put in place a more convincing solution. ${ }^{39}$ According to that provision, the Union-as well as the Member States when implementing EU law-'shall therefore

35 Zimmermann 2014, pp. 184-185, 188-194 and 214.

36 Zimmermann 2014, pp. 221-222; in a similar vein Luchtman 2013, pp. 17 ff.; Böse \& Meyer, Die Beschränkung nationaler Strafgewalten als Möglichkeit zur Vermeidung von Jurisdiktionskonflikten in der Europäischen Union, in Zeitschrift für Internationale Strafrechtsdogmatik 2011, p. 341.

37 Caeiro, Commentary on the 'European Touch' of the Comparative Appraisal, in Substantive Criminal Law of the European Union, ed. Klip (Maklu 2011), pp. 124 and 130.

38 By contrast, an obligation is difficult to establish with regard to the Member States' interest in prosecution. Indeed, the obligation to respect the Member States' 'essential state functions' pursuant to Article 4(2)(2) TEU could serve as a legal basis. However, the only conclusion that can be derived from this vague notion is that any EU measure to prevent conflicts of jurisdiction must be flexible enough to take into account a Member State's special interest in prosecution in a particular case. For details see Zimmermann 2014, pp. 244-246.

39 Zimmermann 2014, pp. 219-221; Borowsky, Article 51 in Charta der Grundrechte der Europäischen Union, ed. Meyer ( $4^{\text {th }}$ edition, Nomos 2014), margin no. 31; in a similar vein -without reference to Article 51(1)(2) CFR- Luchtman 2013, p. 47. 
respect the rights, observe the principles and promote the application thereof (emphasis added). Especially the last subclause is of relevance in the present context. It is submitted that clear European rules on the exercise of criminal jurisdiction would indeed 'promote the application' of the principle of legality (Article 49(1) CFR) as well as the right to a fair trial and a tribunal established by law (Articles 47(2) and 48(2) CFR) because they would help to ensure judicial guarantees in transnational cases.

\subsection{Existing EU legislation}

What has the Union done so far in order to comply with this mandate? The first aspect that deserves being mentioned in this regard is the transnational ne bis in idem rule which was established as early as 1990 in Articles 54 and 55 of the Convention Implementing the Schengen Agreement (CISA). On an international level, it must be regarded as an immense innovation, as before that, the right not to be prosecuted and punished twice was only recognised within one and the same jurisdiction. ${ }^{40}$ Meanwhile, this transnational guarantee has been confirmed-some even say extended ${ }^{41}$-in Article 50 CFR.

In our first case, these ne bis in idem rules help to avoid repeated proceedings in the four Member States involved: as soon as one of them has given a final judgement, proceedings in all other Member States are blocked. The answer to our first question, whether each of the four Member States can prosecute A, is therefore clearly negative. What, however, of our second question, that is, which Member State should prosecute the case? The ne bis in idem rules establish a pure priority regime, which is often called a principle of 'first come, first served' ${ }^{32}$ (and one might incidentally add 'the only one to be served') ${ }^{43}$ Of course this principle entails an immense improvement for the suspect, but only with a view to

40 Satzger 2012, $\$ 8$ margin nos. 64-68 (with further references).

${ }_{41} \quad$ Unlike Article 54 CISA, Article 50 CFR does not make the ne bis in idem guarantee dependent upon an enforcement element, and also the exceptions laid down in Article 55 CISA are not explicitly mentioned. Some authors therefore want to abandon these restrictions, see for instance Swoboda, Paying the Debts - Late Nazi Trials before German Courts: The Case of Heinrich Boere, in 9 JICJ (2011), pp. 265 ff.; Böse, Die transnationale Geltung des Grundsatzes 'ne bis in idem' und das 'Vollstreckungselement'. Zugleich Besprechung von BGH, Beschluss vom 25.10.2010, in Goltdammer's Archiv für Strafrecht 2011, pp. 506 ff.; Vogel 2006, p. 890. However, it appears more convincing to interpret Articles 54 and 55 CISA as secondary law 'limitations' to the primary law guarantee of Article 50 CFR within the meaning of Article 52(1) CFR, see CJEU, C-129/14 PPU Spasic paras. 54 ff.; see also Satzger 2012, \$ 8 margin no. 68; Burchard \& Brodowski, Art. 50 Charta der Grundrechte der Europäischen Union und das europäische ne bis in idem nach dem Vertrag von Lissabon, in StraFo 2010, pp. 179 ff.

$42 \quad$ See COM (2005) 696 final, pp. 3 and 8.

43 Caeiro, Jurisdiction in criminal matters in the EU: negative and positive conflicts and beyond, in KritV 2010, p. 377; Burchard, 'Wer zuerst kommt, mahlt zuerst - und als einziger!' - Zuständigkeitskonzentrationen durch das europäische ne bis in idem bei beschränkt rechtskräftigen Entscheidungen, in Onlinezeitschrift für Höchstrichterliche Rechtsprechung zum Strafrecht 2015, pp. 26 ff. 
repeated proceedings. The other problems caused by conflicts of jurisdiction can in no way be solved by ne bis in idem rules: ${ }^{44}$ these rules only come into play once a final decision has been rendered, they do not provide effective protection against parallel proceedings. Furthermore, it remains a matter of coincidence which Member State is the first to reach a final decision. But should aspects like the sickness of a judge or a delay occuring in the delivery of mail really determine which Member State has the final say? It must be recalled that such factors then ultimately determine the substantive and procedural rules according to which the case will be adjudicated. That does not offer any foreseeability for the suspect, nor can a Member State with a particularly strong and legitimate interest in prosecution be sure that the case will be dealt with in an adequate way. And, even more seriously, this priority regime does not rule out manipulations: two Member States that simultaneously prosecute the same case could informally agree that one of them shall delay its own proceedings in order to make sure that the other one will be the first to come to a final decision.

Therefore, additional rules are needed. But the only ones that can be found are those of a Framework Decision of 2009 which shall serve the 'prevention and settlement of conflicts of jurisdiction. ${ }^{45}$ However, this is a rather clear case of false labelling: according to Article 10(1) of this Framework Decision, 'when it is established that parallel proceedings exist, the competent authorities of the Member States concerned shall enter into direct consultations in order to reach consensus on any effective solution aimed at avoiding the adverse consequences arising from such parallel proceedings, which may, where appropriate, lead to the concentration of the criminal proceedings in one Member State.' And Article 11 continues: 'When the competent authorities of Member States enter into direct consultations on a case [...], they shall consider the facts and merits of the case and all the factors which they consider to be relevant.' In other words, the Member States concerned shall consider the possibility to concentrate the proceedings in one of them. But these provisions neither establish an obligation to concentrate the proceedings-that remains no more than an option-nor do they clarify which criteria may or may not be taken into account. That is why these unregulated consultations have, somewhat provocatively, been called an 'invitation to forum-shop. ${ }^{46}$

\section{Possible Solutions}

This is where our analysis of the status quo ends. In the remaining discussions below, different approaches for a more satisfactory solution to conflicts of criminal jurisdiction

44 Zimmermann 2014, pp. 280-285 with further references.

45 O.J. 2009, L 328/42.

46 European Criminal Policy Initiative, A Manifesto on European Criminal Procedure Law, in Zeitschrift für Internationale Strafrechtsdogmatik (2013), p. 441. 
in the European Union will be assessed. A regulatory model will ultimately be proposed which could avoid the shortcomings identified above.

\subsection{Application of foreign criminal law}

A first option could be the application of foreign criminal law, ${ }^{47}$ a model which is quite common in international private law. ${ }^{48}$ If one accepts that a criminal court does not necessarily have to apply only its domestic criminal law, the question of where to prosecute a case and the one of which law to apply could be separated. As a consequence, it would appear less problematic to choose the forum state on the basis of efficiency considerations, as long as the applicable criminal law is determined by substantive and foreseeable criteria. And indeed such an application of foreign law is not at all something entirely unusual for most criminal justice system ${ }^{49}$ - for instance, every double criminality test implies to a certain extent the application of foreign criminal law..$^{50}$

However, there are several shortcomings of this approach that should not be underestimated. Firstly, it would be very difficult for judges to apply foreign law correctly. Of course this is a general problem that also judges in civil proceedings have to face. But if we take into account that in criminal law uncertainties about the correct meaning of a legal provision are even less acceptable than in other fields of law (as a consequence of the lex certa requirement), the argument remains. A second point is that there are various connections between procedural and substantive law-codes of criminal procedure constantly refer to categories defined by substantive criminal law. For instance, a code of criminal procedure may declare certain investigative measures admissible only for a list of specific offences, or it may restrict the competence of specific courts to a certain number of crimes, or it may grant a legal position—such as the right to have access to the case file-only where a particularly serious offence is being investigated. If a court would have to apply foreign criminal law, then all these references of criminal procedure to substantive law would have to be interpreted in the light of the foreign legal order. But what if that foreign criminal justice system uses a completely different vocabulary? If in our second case, for instance, A was arrested in Sweden, Swedish authorities might have to ask themselves whether the offence of 'assisted suicide' in Austrian law is one for whose investigation Swedish criminal procedure law permits a house search or a telephone tapping. Ultimately that means it would have to be decided on a case by case basis which

47 In this sense Eser \& Burchard 2006, pp. 521 ff.; Böse, Choice of Forum and Jurisdiction in Choice of Forum in Cooperation Against EU Financial Crime, ed. Luchtman (Eleven International 2013), pp. 86 ff.; open for this idea also Eisele 2013, p. 29.

48 See, for instance, Regulation 864/2007, O.J. 2007 L 199/40.

49 Satzger 2012, \$ 3 margin nos. 4-5; see also Helenius, The If, How and When of Criminal Jurisdiction - What is Criminal Jurisdiction Anyway?, in this issue, pp. $41 \mathrm{f}$.

$50 \quad$ Satzger 2012, $\$ 4$ margin no. 41; Helenius 2015, pp. $41 \mathrm{f}$. 
procedural rules apply. Taking into account that these rules often allow for interferences with fundamental rights (as is the case when investigative measures are ordered) and determine the procedural position of the suspect, this would hardly be acceptable from a rule of law perspective. The third and final reason why an application of foreign law does not appear an optimal solution is that every conviction by a criminal court is intended to have a particular stigmatising effect on the convicted person because it expresses the values of the society. But could a court which applies foreign law really express the values of the foreign society-even though it might not always share them?

\subsection{The 'consultation model'}

A second option is what could be called the 'consultation model. ${ }^{51}$ It aims at the solution of conflicts of jurisdiction on a case by case basis, by means of a consensual decision by all Member States concerned. Thus, the particularities of every individual case can be taken into account and there is no need to give priority to a certain criterion. This is certainly the model that is the closest to the Union's current approach, which has been briefly described above. But that also means that the shortcomings are the same: since the decision on the applicable law could only be taken after the act has already been committed, this solution would cause problems for the foreseeability of criminal punishment. Furthermore, there is always a reasonable concern that forum shopping might occur when prosecution authorities of different Member States are allowed to determine the state of trial by means of consultations. As seen above, a criminal justice system based on the rule of law cannot tolerate this risk-irrespective of whether the choice of the forum actually is manipulated.

\subsection{The 'hierarchy model'}

A third option could be an allocation of criminal jurisdiction by means of an EU regulation, i.e. not on a case-by-case basis, but pursuant to abstract rules for all possible cases. The most common concept within this group of proposals is to establish a hierarchy between the different principles of criminal jurisdiction and give priority to one prin-

51 Article 26(2) of the Corpus Juris 2000 in The Implementation of the Corpus Juris in the Member States Volume 1, ed. Delmas-Marty and Vervaele (Intersentia 2000), pp. 206 ff.; the volume Conflicts of jurisdiction in cross-border crime situations, ed. Sinn (Universitätsverlag Osnabrück 2012), pp. 601 ff.; Herrnfeld, Mechanisms for Settling Conflicts of Jurisdiction, in Choice of Forum in Cooperation Against EU Financial Crime, ed. Luchtman (Eleven International 2013), pp. 206 ff.; Lagodny 2001, p. 108; Vander Beken et al. 2002, p. 51; Biehler et al., Freiburg Proposal on Concurrent Jurisdictions and the Prohibition of Multiple Prosecutions in the European Union (Max-Planck-Institut für ausländisches und internationales Strafrecht 2003), pp.14 ff. 
ciple. ${ }^{52}$ Admittedly, this goes beyond the acquis of public international law. ${ }^{53}$ The main objection against this solution is that the best place for prosecution depends on so many factors that it is impossible to create an abstract provision which duly respects them all. ${ }^{54}$ And: Even if such a hierarchy was established, still a solution would have to be found for situations in which several states have an equally strong link to the case, for instance when two states claim jurisdiction on the ground of the territoriality principle. ${ }^{55}$

\subsection{The author's suggestion: a solution combining hierarchy and consultation elements ${ }^{56}$}

What is the way out of this dilemma? A future EU instrument should aim at combining the strengths and avoiding the shortcomings of the different models. Therefore, it is submitted that on an overarching level, the solution should indeed be build upon an abstract hierarchy of jurisdiction criteria. As a matter of principle, only the Member State with the strongest link to the case (which would be determined according to this list) should be allowed to exercise its criminal jurisdiction. This ranking would, as the core of the new instrument, serve to ensure the foreseeability of the applicable law and exclude forum shopping. On a subsidiary level, however, it would have to be complemented by additional rules allowing some necessary flexibility: a 'flexibility clause' could enumerate exceptional circumstances under which a Member State with a lower-ranking link to the case shall have the possibility to suspend the hierarchy. In other words, this provision would function as a kind of 'emergency brake'. Only when the hierarchy does not lead to a clear result or when a Member State pulls the 'emergency brake', should there be room

See the Draft Council of Europe Convention, Recommendation 420 (1965), Assembly debate on $29^{\text {th }}$ January 1965 ( $24^{\text {th }}$ Sitting); Ambos 2011, margin nos. 56 ff.; in a similar vein Fuchs, Regulation of Jurisdiction and Substantive Criminal Law, in A Programme for European Criminal Justice, ed. Schünemann (Carl Heymanns 2006), pp. 364 ff.

53 Ambos 2011, margin nos. 56 et seqq.

54 Lagodny 2001, pp. 48 ff.; Herrnfeld 2013, p. 193; Caeiro 2011, p. 133; Eckstein 2012, p. 504; Schünemann, The Foundations of Trans-national Criminal Proceedings, in A Programme for European Criminal Justice, ed. Schünemann (Carl Heymanns 2006), p. 357.

55 See, for instance, Herrnfeld 2013, p. 193; Caeiro 2011, p. 133; Hecker, Die rechtlichen Möglichkeiten der Europäischen Union zur Lösung von Kompetenzkonflikten, in Conflicts of jurisdiction in cross-border crime situations, ed. Sinn (Universitätsverlag Osnabrück 2012), p. 98; Eser 2012, p. 569. However, this argument can be refuted as the establishment of such a hierarchy would still mean a significant improvement, see Zimmermann 2014, p. 348.

56 For details, including an extensive proposal for such a regulation, see Zimmermann 2014, pp. 369-454. Other 'mixed models' can be found in Böse, Meyer \& Schneider, Conflicts of Jurisdiction in Criminal Matters in the European Union Volume 2 (Nomos 2014), pp. 381 ff.; the volume Conflicts of jurisdiction in cross-border crime situations, ed. Sinn (Universitätsverlag Osnabrück 2012), pp. 606 ff.; as well as the volume A Programme for European Criminal Justice, ed. Schünemann (Carl Heymanns 2006), pp. 258 ff. 
for consultations between Member States. However, detailed rules would have to regulate these consultations.

But before the contents of the proposed instrument can be explained in further detail, some technical questions need to be answered. The first is whether the Union has the competence to adopt such measures at all. Article 82(1)(2)(b) TFEU, which calls for measures to prevent and settle conflicts of jurisdiction, clearly gives a positive answer. ${ }^{57} \mathrm{Sec}-$ ondly, a decision on the legislative form of the instrument must be made. Article 82(1) TFEU confers upon the Union the competence to adopt not only directives, but also regulations. ${ }^{58}$ It is submitted that a regulation would be preferable in the present context because a directive would have to be implemented by Member States. For such a delicate topic, however, a directive would most likely encounter resistance, which would entail a considerable risk of incorrect implementation..$^{59}$

\subsubsection{Level 1: Hierarchy of jurisdiction criteria}

In order to establish a hierarchy, it must first be decided which jurisdictional criteria shall be given priority. To that aim, it needs to be examined to what extent these respect the above-mentioned interests of the individual and of the Member States involved. As a general rule it should be accepted that the easier a criterion makes it to allocate a case to one single Member State, the more weight it should be given. With this in mind, a hierarchy can be outlined as follows:

- The strongest link would have to be the place where the act was performed: since everybody must expect to be treated according to the laws of the place where he acted, this criterion can ensure the foreseeability of criminal punishment better than others. Furthermore, the need to stigmatise the act as unlawful is particularly strong in the place where it was committed. ${ }^{60}$

- This last argument basically also applies with regard to the place where the effects of the act occur. However, our second case illustrates quite well that this is an aspect which can depend upon coincidence. At least theoretically, it can even allow for manipulations, for instance if $\mathrm{T}$ - the fatally poisoned victim — is brought to a different Member State and dies there. Thus, the place where the act causes a result should only be the second-strongest criterion in the hierarchy.

$57 \quad$ For a more thorough analysis see Böse, Meyer \& Schneider 2014, pp. $367 \mathrm{ff}$.

58 Satzger 2012, $\$ 8$ margin no. 46.

59 For the adoption of a directive Herrnfeld 2013, pp. 200 and 202.

60 Zimmermann 2015, p. 170. According to Böse, Meyer \& Schneider 2014, p. 390, the causation of an effect should only establish criminal liability in the Member State where the perpetrator acted if the causation of said effect was also criminalised in the Member State where it occurred. 
- Only in cases where neither the act is committed nor an effect produced on one Member State's territory, should the nationality (or the place of residence) of the offender be decisive: ${ }^{61}$ although this criterion will normally make sure that the case is adjudicated according to substantive criminal provisions which are well known to the perpetrator, it is less convincing than those based on the principle of territoriality. This is mainly because the suspect is often unknown at an early stage of the proceedings (not to mention the presumption of innocence).

- The nationality (or place of residence) of the victim should only come into play in the fourth place. ${ }^{62}$ The reason is that many offences do not affect an individual; and if they do, the perpetrator will not necessarily know where the victim is from.

- The flag principle, which has traditionally served as a mere substitute for stronger links, ${ }^{63}$ should be put in the fifth place of the ranking, so that it does not come into play if the vessel is in the territorial waters of a Member State when the offence is committed or if the principles of active and passive personality apply. It should be followed by all further jurisdiction criteria recognised by international public law.

If two Member States can base their interest in prosecution on an equally strong link, the one which additionally has the next strongest link should be competent to adjudicate the case-a method which can be called 'accumulation principle.' ${ }^{64}$ If, for instance, a German national drinks a bottle of wine in Munich and then drives across the border to Austria, the act of drunk-driving is committed in Germany and Austria. ${ }^{65}$ But since the offender is German, only Germany would be allowed to exercise its jurisdiction.

Some readers might have noticed that the principle of state protection does not appear in the list of criteria. This is because it largely depends on each state's sensitivity which crimes are regarded as so severe attacks against the society that they shall fall under that

(1)
This part of the proposal was inspired by Lelieur-Fischer, Comments on the Green Paper on
Conflicts of Jurisdiction and the principle ne bis in idem in criminal proceedings (Max-Planck-
Institut für ausländisches und internationales Strafrecht 2006), pp. 12-13; Ambos 2011, margin no. 63.

65 Very complicated questions arise when the assessment of the act differs considerably, for instance when the blood alcohol concentration exceeds the tolerated level on one side of the border, but not on the other. In such cases, the CJEU case-law on the identity of acts in the sense of Article 54 CISA (see C-436/04 'van Esbroeck' ECR 2006, I-2333) does not offer a satisfactory solution. Rather, it should be considered to make an exception and regard the events on the two sides of the border as different acts, see Zimmermann 2014, pp. $416 \mathrm{ff}$. 
state's jurisdiction even when committed abroad and by foreigners. ${ }^{66}$ For reasons of foreseeability, such normative aspects should not be considered on the first level, i.e. in the overarching hierarchy. Likewise, it should not be relevant at this stage how strong the country's link to the case as established by the enumerated criteria is in reality (e.g. if an act committed on one Member State's territory was still one of preparatory nature or already constituted the main act of the offence). Finally, procedural aspects like the location of evidence or the place where the suspect is arrested have been left out because they depend upon coincidence.

\subsubsection{Level 2: Flexibility clause}

On the second level, a flexibility clause needs to be drafted. Here, several normative aspects can be taken into account. But since this 'emergency brake' must not lose its exceptional character, these aspects should be enumerated in an exhaustive list. It should be a general prerequisite for all categories that a decision in the Member State with the strongest link would not sufficiently take into account these special circumstances. This is conceivable if that state is unable or unwilling to prosecute ${ }^{67}$ or if its assessment of the legal wrong deviates completely from that in the Member State with the weaker link.

This catalogue should be limited to

- essential interests of state security,

- offences that are committed by public agents of a Member State,

- serious tax offences,

- cases in which victim and offender have the same nationality and

- cases where a state with a weaker link would violate its international obligations if it left the prosecution to another Member State. ${ }^{68}$

Finally, one more flexible criterion could be included, namely that the prosecution proves indispensable for the state with the weaker link in order to defend its fundamental values. Of course that last criterion bears a certain risk of abuse. Therefore, it should be an additional requirement that according to the law of the Member State with the weaker link a prison sentence is to be expected which-due to its lengthwill actually be enforced and cannot be suspended. ${ }^{69}$

\footnotetext{
66 Zimmermann 2014, pp. $270 \mathrm{ff}$.

67 This formula stems from Article 17 of the Rome Statute of the International Criminal Court. This idea already shines up in Biehler et al. 2003, pp. 32-33.

68 Even more restrictive Böse, Meyer \& Schneider 2014, pp. $392 \mathrm{ff}$.

69 The notion 'suspended sentence' is taken from Art. 2 no. 2 of Framework Decision 2008/947/ JHA, O.J. 2008 L 337/102.
} 


\subsubsection{Level 3: Strictly regulated consultations as a measure of last resort}

In a third stage, consultation proceedings should be initiated if a Member State pulls the 'emergency brake' or if it proves impossible to define one competent state on the basis of the hierarchy. However, these consultations would have to differ considerably from those provided in the Framework Decision on the prevention of conflicts of jurisdiction:

- As we have seen, it is one of the most essential interests of the defendant to avoid parallel proceedings. It should therefore be compulsory to concentrate proceedings in one Member State. If the Member States involved do not come to a consensual solution, this should therefore be decided by an independent and impartial authority. ${ }^{70}$ This could be a task for Eurojust, ${ }^{71}$ at once when the institutional foundations have been laid. ${ }^{72}$

- In order to exclude forum shopping, there should be an exhaustive list of criteria that may be considered when the decision on the forum state is made. In this third stage, these could be both normative and pragmatic criteria, such as how strong the interests of the Member States involved actually are, where a proceeding would be most efficient, whether an effective defence will be possible and how easily victims can participate.

- It needs to be ensured that the consultations are fully transparent. This requires a very thorough documentation of all reasons for the decision on the forum state. Furthermore, the consultations should be supervised by the neutral authority (possibly Eurojust). Also the suspect (or his counsel) should have the right to be heard and be present at the consultations, at least unless this would put the investigations at risk.

- Finally, the decision on the forum state must be subject to full judicial control. The representatives of the Member States must therefore not enjoy any discretion.

71 Article 2(4), A Programme for European Criminal Justice, ed. Schünemann (Carl Heymanns 2006), pp. 259 and 261; Suominen, The Past, Present and Future of Eurojust, 9 MJECL (2008), p. 233; Massa, Jurisdiction in England and Wales and in the Netherlands: a comparative appraisal with a European touch, in Substantive Criminal Law of the European Union, ed. Klip (Maklu 2011), p. 120; Eisele 2013, pp. 11 and 23-24.

72 Some authors argue that the structure of Eurojust is better apt for a consensual settlement of conflicts of jurisdiction, see Lagodny 2001, p. 126; Herrnfeld 2013, p. 201. However, this does not rule out that it could be given a more dominant role de lege ferenda. 


\subsubsection{Some collateral provisions}

If an EU regulation which respects these guidelines is adopted, at least the big majority of cases could be dealt with in an appropriate way. However, several additional rules would have to be established for more complicated cases, particularly such involving more than one person. Since this is not the place to describe these in detail, some brief remarks will have to suffice: it should be distinguished between acts by different persons with a material connection ${ }^{73}$ and those with a rather loose connection. In view of the first ones, criminal jurisdiction should, in a single area of justice, be exercised by only one Member State in order to ensure that they are treated consistently. This should be the Member State which has the strongest connection to the totality of the acts. With regard to the latter - for instance different offences committed in the framework of one criminal organisation - concentration of proceedings is of course desirable. The same applies for different acts committed by one person. Thus, inter-state consultations for this purpose do make sense. But Member States should not be obliged to concentrate proceedings simply due to a loose connection between the acts. It follows that also a subsidiary decision by Eurojust would not be necessary in those situations.

$\mathrm{One}^{74}$ of the more technical aspects which should be considered is that abuses of the new jurisdiction regime must be prevented. Therefore, the Member State which is competent to exercise criminal jurisdiction according to the new regulation should - if the act is punishable according to its law - be expressly obliged to duly investigate and prosecute the case, at least if another Member State has signalised its interest in prosecution. In particular it should not be allowed to dispense with prosecution after such notification without the other Member State's consent. Finally, the circumstances must be defined which, by way of exception, allow for a reopening of the proceedings after a final decision was handed down in one Member State. ${ }^{75}$ One case where this should be considered is when the Member State competent to exercise jurisdiction failed to comply with its obligation to duly carry out the investigation or prosecution. ${ }^{76}$

73 Such a material connection exists when the acts of different persons shall serve the implementation of a common plan or when the act of one person is knowingly induced or supported by the act of another person; see Zimmermann 2014, pp. $422 \mathrm{ff}$.

$74 \quad$ Further provisions would have to oblige Member States to communicate as soon as they become aware that a case has cross-border elements. Furthermore, the point in time from which on the hierarchy becomes binding needs to be determined, as well as possibilities to change the Member State of trial if new evidence is discovered later. For this last aspect see Article 2(5), A Programme for European Criminal Justice, ed. Schünemann (Carl Heymanns 2006), p. 259; for details on the necessary corollary provisions see Zimmermann 2014, pp. 434-443.

75 This would not violate Article 50 CFR; see Article 52(1) CFR.

76 The respective provision could be inspired by Articles 17 and 20 of the Rome Statute; see once again Biehler et al. 2003, pp. 32-33. 
Since one of the chief objectives of this proposal is to ensure the foreseeability of the applicable law, a final suggestion would be to include a general proviso for cases where none of the detailed rules outlined above offers a sufficient solution. Such a 'transnational principle of legality' could be formulated as follows:

An act may be punished by a Member State only insofar as the citizen concerned could foresee the applicability of that Member State's criminal law in the particular case, or at least had reason to expect a sanction which would have been comparable in terms of its type and severity. ${ }^{77}$

This would ensure that nobody is punished more harshly than according to the laws which he could be expected to obey.

\section{$4 \quad$ Concluding Remarks}

Of course this contribution cannot end without proposing a solution for the two cases that were taken as a starting point. On the basis of the regulation proposed here, the first case would be easy to handle: of the Member States concerned, Germany has the strongest link because the offender A acted in Munich. Therefore, only Germany could exercise criminal jurisdiction over the case. In the second case, the abstract hierarchy would lead to the result that only Germany could prosecute the case because A (and T) acted on German territory. However, Austria might want to prosecute the case in order to defend its fundamental values, and such particular interest in prosecution would be neglected according to the hierarchy because the act is not criminalised in Germany. But if Austria therefore invoked the flexibility clause and consultations were initiated, two aspects to be considered would certainly be the lack of foreseeability, as well as that both offender and victim were German nationals. ${ }^{78}$ An overall assessment of the case would thus lead to the conclusion that German criminal law applies. Since the conduct is not criminalised in Germany, A would thus ultimately not have to fear punishment.

Of course an allocation of jurisdiction as proposed here is a highly controversial issue. Professionals who have been working in this field will most probably, without great difficulties, be able to imagine or refer to cases where the model presented above comes to its limits. However, this contribution should—at least—have shown that it is possible to develop a solution which effectively guarantees fundamental rights of criminal law and procedure in cross-border cases. Moreover, such a solution could even be based on a hierarchy model as long as it is reasonably complemented with flexible elements. Therefore, the European legislator should no longer hesitate to face this challenge.

77 Compare Zimmermann 2014, pp. $431 \mathrm{ff}$. A similar solution is offered by Böse, Meyer \& Schneider 2014, pp. $382 \mathrm{ff}$., who require intent or negligence with regard to the circumstances that make the prosecuting Member State's criminal law applicable.

This is another category enumerated in the flexibility clause as suggested above. 